спрямованих на підтримку розвитку якісних учителів в Австралії. По-друге, активна підтримка професійного розвитку вчителів надається різними професійними організаціями Австралії, які орієнтуються не тільки на національні стандарти, вимоги і форми професійного розвитку вчителів, а й на глобальні тенденції у професійному навчанні.

\title{
Література
}

1. Australian Charter for the Professional Learning of Teachers and School Leaders. AITSL, 2012. - 10 p. 2. Australian Qualifications Framework. - Australian Qualifications Framework Council, 2013. - 112 p. 3. Australian Teacher Performance and Development Framework. - AITSL, 2012. - 14 p. 4. Certification of Highly Accomplished and Lead Teachers in Australia. - AITSL, 2012. - 26 p. 5. Dennis Sparks. Designing powerful professional development for teachers and principals / Sparks Dennis. - Oxford: National Staff Development Council, 2002. - 153 p. 6. Designing Professional Learning. - AITSL, 2014. - 30 p. 7. Global trends in professional learning and performance \& development. Some implications and ideas for the Australian education system. - AITSL, 2014. - 36 p. 8. Katarina Tuinamuana. Teacher Professional Standards, Accountability, and Ideology: Alternative Discourses / Tuinamuana Katarina // Australian Journal of Teacher Education. 2011. - Vol. 36. - № 12. - P. 72-82. 9. National Professional Standards for Teachers. AITSL, 2011. - 24 p. 10. The Senate. Education, Employment and Workplace Relations References Committee. Teaching and learning - Maximising our investment in Australian schools. - Commonwealth of Australia, 2013. - 116 p.

Ілона Сіліванова

\section{ГЕНЕЗА РОЗВИТКУ МІЖНАРОДНОЇ АКАДЕМІЧНОЇ МОБІЛЬНОСТІ В УНІВЕРСИТЕТАХ ФРАНЦЇ̈}

Сіліванова I. М. Генеза розвитку міжнародної академічної мобільності в університетах Франції.

Стаття присвячена проблемі генези та етапів розвитку міжнародної академічної мобільності іноземних студентів в університетах Франції. Метою статті $є$ визначення історичних передумов процесу академічної мобільності та виокремлення i аналіз етапів розвитку. 3'ясовано, що міжнародна академічна мобільність в університетах Франції - це історичне явище, яке набуло популярності одночасно із заснуванням перших європейських університетів.

Ключові слова: міжнародна академічна мобільність, університет, іноземний студент, мобільний студент, міжнародний студент, вхідна мобільність.

Силиванова И. М. Генезис развития международной академической мобильности в университетах Франции.

Статья посвящена проблеме генезиса и этапов развития международной академической мобильности иностранных студентов в университетах Франции. Целью статьи является определение исторических предпосылок академической мобильности, выделение и анализ этапов развития. Выяснено, что международная академическая мобильность в университетах Франции это историческое явление, которое стало популярным с появлением первых европейских университетов.

Ключевые слова: международная академическая мобильность, университет, иностранный студент, мобильный студент, международный студент, входящая мобильность. 
Silivanova I. M The historical development of international academic mobility in French universities.

The article is dedicated to the problem of genesis and the phases of development of international academic mobility in French universities. The aim of the article is to define historical preconditions of this process and analyze phases of its development. It was found out that international academic mobility in French universities is a historical phenomenon which gained its popularity with the appearance of the first European universities.

Key words: international academic mobility, university, foreign student, mobile student, international student, inbound mobility.

Проблема академічної мобільності як можливість навчання студентів упродовж певного періоду в зарубіжній освітній або науковій установі була і залишається невід'ємним складником університетського життя у Франції. Вищі навчальні заклади Франції, які завжди вважалися найбільш престижними інституціями в Свропі, мають багатий досвід роботи $з$ іноземними студентами. 3 моменту свого зародження, раннє Середньовіччя (XII ст.), французький університет і донині продовжує бути основним елементом, який дозволяє вільне переміщення французьких студентів та забезпечує прийом іноземних студентів до Франції у межах програм міжнародної співпраці університетів-побратимів.

Однією з причин популярності французьких університетів поміж міжнародних студентів $є$ підготовка висококваліфікованих фахівців, конкурентоспроможних як на вітчизняному, так і світовому ринках праці. Проте плюралістична відкритість університетів відіграє не останню роль $[10$, с. 4]. Однакові умови для навчання створені для французьких студентів, і студентів-вихідців 3 усіх п'яти континентів. Наприклад, станом на 2003-2004 навчальний рік 51,2\% французьких студентів $€$ вихідцями з Африки, 24,5 \% з Свропи, 17,5 \% 3 Азії та Океанії та 6,8 \% 3 Північної та Південної Америки [10, с. 15].

Варто зазначити, що упродовж останніх кількох років ми спостерігаємо позитивну динаміку впровадження програм індивідуальної та групової академічної мобільності і в Україні. Однак на цьому шляху наша країна натрапляє на низку проблем, розв'язанню яких сприятиме аналіз досвіду основних країн-провайдерів академічної мобільності у світі, зокрема Франції. Актуальність нашої статті зумовлена необхідністю більш детального вивчення процесу встановлення академічної мобільності у Франції, визначення його історичних передумов, виокремлення й аналіз етапів розвитку.

Дослідження процесу встановлення та розвитку міжнародної академічної мобільності Франції стало предметом вивчення багатьох іноземних науковців. Жак Вержи досліджує мобільність у французьких університетах з моменту їх зародження у період Середньовіччя, Елізабет Морне розглядає подорожі вельможних датчан на навчання до Франції у часи Реформації, П'єр Мулін'є аналізує студентське життя іноземців у Парижі в XIX столітті, Віктор Караді - міжнародні міграції європейських студентів до Франції. На сучасному етапі Ясміна Беттахар та Франсуа Бірк аналізують «нові полюси» привабливості вищої освіти у Франції у XX столітті, тоді як Фабієн Гімон аналізує найбільш численну касту африканських студентів у Франції у середині XX - на початку XXI століть.

3 огляду на те, що проблема генези та етапів розвитку міжнародної академічної мобільності студентів в університетах Франції є недостатньо дослідженою в Україні, метою статmі є визначення історичних умов, окреслення та класифікація етапів 
розвитку академічної мобільності у Франції.

Для того щоб комплексно проаналізувати генезу поняття «академічна мобільність» та виокремити етапи його розвитку в університетах Франції, насамперед, потрібно осмислити роль, яку відіграв французький університет у цьому процесі. Необхідно зазначити, що перше об'єднання викладачів та студентів виникло у Франції у середині ХІІ століття. Паризькі монастирські та кафедральні школи Сен Жермен де Пре, Сен-Женев'єв, Сен-Віктуар і школи Латинського кварталу об'єдналися та утворили один 3 перших університетів у Європі, а саме Паризький університет ( l'Université de Paris), пізніше перейменований на університет Сорбонна (l’Université de Sorbonne) [3, с. 174]. Паризький університет (рік заснування 1208 1209 pр.) став освітнім і культурним центром Франції та активно приймав не лише місцевих, але й іноземних студентів 3 різних християнських країн. Першими студентами, що прибули навчатися на територію Франції, були юнаки, які бажали піднятися на вищий щабель релігійної ієрархії [1, с. 21]. Відповідно, першими факультетами у вищезгаданих університетах були факультети богослів'я та медицини. У царині освіти авторитет церкви був беззаперечним, а священнослужителі визначали зміст навчальних програм [2, с. 14].

Міграційні студентські процеси досить швидко стають настільки потужними, що спричиняють не лише побутові, але і юридичні проблеми. В історичних хроніках йдеться про те, що потік студентів в основних навчальних центрах спричинив проблеми, пов'язяні із забезпеченням житлом, продуктами харчування та громадського порядку. Присутність іноземних студентів викликала невдоволення місцевих жителів, але вони не уникали можливості використати учнів у власних цілях. Звичаєве право захищало лише місцевих жителів; іноземці, які у своїй більшості були студентами, страждали від поборів та свавілля представників місцевої влади.

Проблеми, пов'язані з утриманням іноземних студентів, створили передумови для розроблення та затвердження римським імператором Фрідріхом I Барбаросса Конституції Habita у 1155-1158 р. Цей закон установив, що «жоден іноземний студент, який відчуває любов до науки не може бути підданий репресіям (тобто нести відповідальність за борги чи злочинні дії, вчинені його співвітчизниками)». Текст імператорської Конституції був одразу надісланий королю Франції Філіпу II Августу, але потрібно було чекати 1200 р. для того, щоб його син Людвіг VIII надав паризьким студентам право користуватися такими ж привілеями, як і решті громадян, i взяв їх під свій протекторат [9, с. 67].

Завдяки контролю Папства було також узгоджено зміст навчальних дисциплін і навчальні методи. В епоху раннього Середньовіччя латина набуває статусу мови викладання та спілкування. В усіх тогочасних університетах практикують лекції, диспути, читають твори одних і тих самих науковців. Навчальні програми, термін навчання, система екзаменів та оцінювання були аналогічними усюди [9, с.68]. Уніформізація навчального процесу сприяє затвердженню також однакові наукові ступені. Починаючи 31230 р. науковий ступінь, отриманий у певному університеті, мав чинність у межах всіх християнських країн, а документ licentia ubique docendi (дослівно 3 лат. «право навчати будь-де») дозволяв власнику викладати у будь-якій країні без необхідності складати додатковий іспит на професійну придатність.

3 часом дипломи, отримані у Франції, нівелюються. Так, у часи Папської схизми (розкол у римо-католицькій церкві 1378-1417 рp.) мобільність студентів послаблюється. Французький дослідник Жак Вержи у статті, присвяченій географічній наповненості французьких університетів на початку XV ст., зазначає, що 
в університетах Орлеана, Анже, Парижа та Тулузи кількість німецьких, італійських та англійських студентів становила від 6 до $20 \%$, тоді як в університеті Авіньйона навчалося лише 20 \% жителів Провансу. Решта студентів університету Авіньйона прибували із сусідніх країн і були більш зацікавлені в папському дворі, аніж рівнем викладання дисциплін. Зменшення потоку студентів було також спричинено тогочасними «бідами», а саме Столітньою війною з Англією та Великою чумою [9, c. 78].

Науковець Елізабет Морне, здійснюючи дослідження, присвячене навчанню датських студентів за кордоном, дійшла висновку, що основними учасниками освітніх подорожей у XIV - XVI ст. були дворянство та знать, які мали достатньо коштів та зв'язків для того, щоб поїхати на навчання в іншу країну. Було дві категорії «академічних паломників». Першу становили забезпечені приватні особи, які могли дозволити собі поїхати на навчання за кордон. Другу категорію складали приватні особи, яких фінансували церковнослужителі певної єпархії. Відповідно, уже в той час ми можемо спостерігати тенденцію, що дистанція подорожі прямопропорційно залежала від соціального статусу та фінансового забезпечення студента [5, с. 301].

Визначальною рисою наступного етапу, який тривав з кінця XVI ст. і розпочався 3 розквітом Ренесансного гуманізму, є навчання мандрівних студентів у кількох університетах. Спочатку такі студенти відвідували регіональний університет, пізніше продовжували навчання у закладі, де якісно викладали певні дисципліни та за незначну плату отримували вчений ступінь у третьому. Такі подорожі стали початком так званих Гранд Тур (Grand tour), у яких брали участь молоді аристократи у XVIIXVIII ст. Ця епоха також позитивно впливає на інтелектуально-духовний розвиток XVI ст. Франциску I вдається закріпити статус французької мови і перетворити університет на освітній заклад, де навчання базується не на схоластиці, а філології. У цей час найбільш престижним факультетом серед іноземних студентів вважався факультет гуманітарних наук у Паризькому університеті, куди їхали вивчати граматику, риторику, діалектику, астрономію, арифметику, геометрію та музику [2, c. 18].

Контингент іноземних студентів в університетах стає більш однорідним, починаючи з XVII ст. Університети намагаються утримувати монополію на знання, наполягаючи на своїх середньовічних привілеях. Просвітницький абсолютизм, прагнення централізації та військової модернізації вимагають розвитку більш динамічних і прагматичних структур, таких як Академії наук. У XVIII ст. кількість французьких та іноземних студентів поступово зменшується через те, що навчальні програми не відповідають потребам часу (лише у трьох університетах вивчали диференціальне та інтегральне числення, аналітичну геометрію, фізику). Крім того, плата за навчання була дуже високою (повний курс медицини в Парижі коштував близько 7000 ліврів- 2300 золотих карбованців, не беручи до уваги вартість проживання). У 1793 р. університети тимчасово припиняють своє функціонування. На їх зміну створюються школи різного профілю (Військова школа, Школа мистецтва та ремесла, Школа підготовки вчителів) [2, с. 15].

Третій період (кінець XVIII ст. - 70 pp. XX ст.) характеризується відродженням занепалого університету та активізацією процесу академічної мобільності у Франції. Університетом тепер називається об'єднання державних та приватних навчальних закладів, у яких професорсько-викладацький склад, навчальні програми, форми та методи навчання визначаються імператором. Університетом керував гранд-метр, якого призначав на посаду Наполеон Бонапарт.

За часів Наполеона III вища освіта та розвиток університетів не були 
першочерговим завданням, змін зазнала лише початкова освіта (Закони Франсуа Гізо, Альфреда Фаллу, Віктора Дюрюі, Жуля Феррі). Відсутність статичної інформації щодо кількості іноземних студентів на території Франції до 1870 р. не дозволяє об’єктивно проаналізувати стан академічної мобільності. Достеменно відомо, що 3 1832 по 1860 привілеями при вступі у французький університет користувалися біженці з Польщі, Румунії, Італії. Іноземців з Великобританії Ірландії, Швейцарії та Німеччини найбільше приваблював медичний факультет та факультет права.

Зростання кількості іноземних студентів стає очевидним з моменту заснування за кордоном, а саме у Греції, Румунії, Сгипті і Турції французьких коледжів професійного спрямування. Окрім того, створення у 1883 р. культурно-просвітницької організації Альянс Франсез (Alliance française) задля популяризації французької культури у світі. Також відбулося спрощення правил прийому іноземних студентів (звільнення від екзаменів), організація курсів французької мови для іноземців. 31891 р. у кожному університеті створюється Комітет підтримки іноземних студентів (le Comité de patronage des étudiants étrangers), який пропонує літні курси 3 вивчення французької мови. За ініціативи Національного агентства університетів та шкіл Франції (Office national des universités et écoles françaises) 3'явилися брошури для іноземних студентів, у яких подавалися рекомендації для мобільних студентів у Франції [6, с. 132].

Французько-угорський дослідник Віктор Караді визначає, що основу іноземного студентства в університетах Франції у кінці XIX на початку XX ст. становили національно-етнічні меншини. Самодержавна політика Російської імперії щодо обмеження прийому євреїв у вищі навчальні заклади та невирішеність питання доступу жінок до вищої освіти змусили ці категорії населення емігрувати та здобувати освіту у Франції. У $1899-1990$ рр. частка російськомовних студентів в університетах Франції становить $20 \%$. До цієї хвилі еміграційного руху також приєдналися жителі Польщі, які не бажали бути русифікованим [6, с. 136]. Важливою характеристикою процесу академічної мобільності цього періоду стала також зміна контингенту студентів за статтю. Кількість осіб жіночої статі, які навчалися в університетах Франції, перевищувала кількість чоловіків. Так, наприклад, станом на 1905-1906 pp. у Парижі 57 \% іноземних студентів є особами жіночої статі [4, с. 53].

Одним із нововведень у міжвоєнний період стало навчання зі статусом «вільного слухача», яке дозволяло отримати Сертифікат про відвідування занять (Certificat d'assiduité). У 1934-1935 pp. 46 \% іноземних студентів із західної та східної Європи відвідували лекції з вибраної спеціальності без складання іспитів. Окрім того, у 1936 р. міністр Народного Фронту Жан Зай створює Регіональний центр університетських та шкільних справ (Centre régional des œuvres universitaires et scolaires - CROUS). Метою заснування центру стало надання допомоги іноземним студентам у забезпеченні житлом, харчуванням, у виплаті соціальної допомоги чи стипендії та організації дозвілля.

Відлік четвертого етапу академічної мобільності розпочинається із 70 -х років минулого століття і триває до сьогодні. Процес академічної мобільності підсилюється Болонським процесом, посиленням євроінтеграції та глобалізації, доступністю освіти загальним масам та активною політикою уряду Франції з метою збереження статусу країни - провайдера якісної та елітної міжнародної освіти.

Декрет від 13 травня 1971 р. щодо запису іноземних студентів у державні університети вперше визначає необхідність складання тесту на знання французької мови для того, щоб «бути готовим до обраної спеціальності». Циркуляр від 12 грудня 1977 р., підписаний Міністром внутрішніх справ Шарлем Боне за підтримки Міністерства закордонних справ, установлює жорсткіший контроль за кількістю 
іноземних студентів. Цей офіційний документ обмежував доступ іноземних студентів на перший цикл навчання (ліцензіат) і зобов'язував їх повернутися ув рідну країну по закінченню навчання. Дозвіл на довготермінове перебування іноземний студент міг отримати лише у випадках, якщо він подав: 1) свідоцтво про попереднє зарахування до вищого навчального закладу Франції; 2) витяг з банківського рахунку з балансом не менше 13500 франків на рік, що дорівнює сумі стипендії французького уряду; 3) довідку про стан здоров'я. Однак ці зобов'язання не стосувалися вихідців із країн-членів Європейської економічної спільноти та стипендіатів французького уряду [7, с. 45].

Постанова від 31 грудня 1979 р., а саме, «декрет Імбера» деталізує умови вступу до вищого навчального закладу Франції, а саме: запроваджує обов'язкову наявність диплома про повну середню освіту, який дозволяє отримати вищу освіту в рідній країні чи за кордоном і визначає обов'язкові іспити на знання французької мови для іноземців 3 нефранкомовних країн. Ще одним нововведенням стало положення про попередній запис іноземних студентів, який стає обов'язковим для тих, хто вперше буде навчатися у вищому навчальному закладі Франції [8, с. 185]. 3 цією метою було створено Національний комітет запису іноземних студентів (Commission nationale pour l'inscription des étudiants étrangers). Процедура попереднього зарахування до університету, затверджена декретом Імбера, збереглася у Франції до 1982 р. 26 липня 1982 р. Сенат Франції скасував перевірку та відбір досьє при Національному комітеті по запису іноземних студентів.

Позитивна динаміка збільшення кількості іноземних студентів спостерігається у Франції з 1998 р. Поворотною подією стає рішення розпочати Болонський процес та заснувати європейський простір вищої освіти. Розпочатий за ініціативи міністра національної освіти Франції Клода Аллегра, Болонський процес мав на меті сприяти обміну студентів, викладачів та науковців. Для того щоб підвищити кількість мобільних студентів, першочерговими завданнями стали гармонізація системи освіти, запровадження загальноприйнятої системи наукових ступенів та європейської кредитно-трансферної системи.

15 червня 2000 р. було прийнято найважливіший документ в історії сучасної освіти Франції, а саме Закон про освіту (Code de l'éducation). У статті 123 Освітнього кодексу визначено участь Франції у розбудові Європейського простору вищої освіти та прагнення міжнародної співпраці. У рамках міжнародної співпраці університетам дозволено створити або адаптувати існуючі спеціальності до потреб мобільних студентів. У статті 714-7 також визначається обов'язковість створення на базі університету чи групи університетів Відділу міжнародних зв'язків, що буде відповідати за прийом іноземних студентів, інформувати їх про навчальні та наукові програми, перевіряти знання французької мови, іноземні дипломи студентів, їх загальну здатність навчатися на обраних спеціальностях та організовувати вступні лекції на факультетах та заняття з французької мови та цивілізації.

Однак, поруч із популярними кроками на шляху до збільшення кількості іноземних студентів, уряд, який прийшов на чолі з новообраним Президентом Франції Ніколя Саркозі, запам'ятався і певними негативними нововведеннями. 21 травня 2011 р. у силу вступив «циркуляр Геана», який стосувався іноземних студентів, що не $\epsilon$ вихідцями $\mathrm{CC} \mathrm{i} \mathrm{які} \mathrm{бажають} \mathrm{після} \mathrm{завершення} \mathrm{навчання} \mathrm{продовжити} \mathrm{свій}$ професійний досвід у Франції. Метою циркуляру стало обмеження кількості студентів-іммігрантів, яким було відмовлено у праві на роботу. Поясненням такого рішення стала надмірна кількість нелегальних іммігрантів у Франції станом на 2011 р. Циркуляр було скасовано у травні 2012 р. новообраним Президентом Франції Франсуа Олландом та його командою. Такий епізод в історії Франції суттєво 
применшив імідж цієї країни як такої, що створює усі можливі переваги для навчання іноземних студентів.

Проаналізувавши проблему генези академічної мобільності у Франції, можна стверджувати, що студентська мобільність у цій країні- це історичне явище, яке набуло популярності одночасно з заснуванням перших європейських університетів. Розвиток студентської академічної мобільності у Франції завжди визначався різними чинниками, а саме: церквою, політичною ідеологією правлячого уряду, демографічними показниками, економічним станом країни. Упродовж першого досліджуваного періоду (XII - поч. XVI ст.) відбулася уніформізація навчальних програм, термінів навчання, системи оцінювання. Студентська мобільність мала індивідуальний спонтанний характер та відбувалася завдяки благодійності церковнослужителів. Визначальною рисою другого етапу (XVI - кінець XVIII ст.) стало навчання мандрівних студентів у кількох університетах країни. Також відбулися зміни, що стосувалися мови викладання та вивчення основних навчальних предметів. Третій період (кінець XVIII ст. -70 pp. XX ст.) видався багатим на події, які вплинули на активність розвитку академічної мобільності. У цей період відбувається трансформація французького університету та зміна навчального контингенту. Відтепер основу мобільного студентства становили національно-етнічні меншини 3 Росії, Польщі, Румунії, Єгипту. Кількість мобільних студентів у Франції в цей період залежить від роботи новостворених національних агенцій, міжнародних організацій, об'єднань університетів та французьких коледжів за кордоном. Відлік четвертого етапу почався 3 70-х років минулого століття і триває дотепер. Нині університети конкурують у залученні ще більшої кількості мобільних студентів. Намагаючись утриматися у трійці європейських лідерів 3-поміж країн-провайдерів вищої освіти, уряд Франції заохочує іноземних студентів до вибору саме французьких університетів, запровадивши Болонський процес, спростивши можливість вступу, тимчасового працевлаштування й отримання візи. Однак, зважаючи на те, що конкурентоздатність інших європейських університетів невпинно зростає, уряд Франції жодною мірою не повинен зупинятися на досягнутому.

\section{Література}

1. Вербицька С. В. Міжнародна студентська академічна мобільність: етапи розвитку та суб'єкти організації/ С. В. Вербицька //Вісник Житомирського державного університету. Педагогічні науки. - 2009. - № 45 - С. 15-19. 2. Лаухіна І. С. Релігієзнавчи й компонент змісту загальної середньої освіти Франції: автореф. дис... канд. пед. наук: 13.00.01 / $\quad$ I. С. Лаухіна. - К., 2013. - 20 с. 3. Орехова Е. Я. Французький университет: размишления о культуре и традициях в современном образовании // Вестник Томского государственного педагогического университета. - 2004. - № 5 - C. 174-179. 4. Karady Victor. La migration internationale d'étudiants en Europe, 1890-1940 / V. Karady // Actes de la recherche en sciences sociales. La circulation internationale des idées. - décembre 2002. - Vol. 145- PP.47-60. 5. Mornet Elizabeth. Le voyage d'études des jeunes nobles danois du XIVe siècle à la Réforme // Journal des savants. - oct.- déc. 1983. - № 4 - P. 287-318. 6. Moulinier Pierre. Les etudiants etrangers à Paris au XIXe siècle/Pierre Moulinier. - Rennes: PUR, 2011. 425 p. 7. Sylvie Mazzella. La mondialisation étudiante. Le Maghreb entre Nord et Sud/Sylvie Mazzella. - Paris: Karthala, 2009. - 404 p. 8. Serge Slama. La fin de l'étudiant étranger/ Serge Slama. L'Harmattan, 1999. - 312 p. 9. Verger Jacques. La mobilité étudiante au Moyen Âge / J. Verger // Histoire de l'education. - 1991. - № 50 - P. 65-90. 10. Alain Coulon Saeed Paivandi. Les étudiants étrangers en France: l'état des savoirs / A. Paivandi // Rapport pour L'Observatoire de la Vie Étudiante. - mars 2003. - 53 p. 